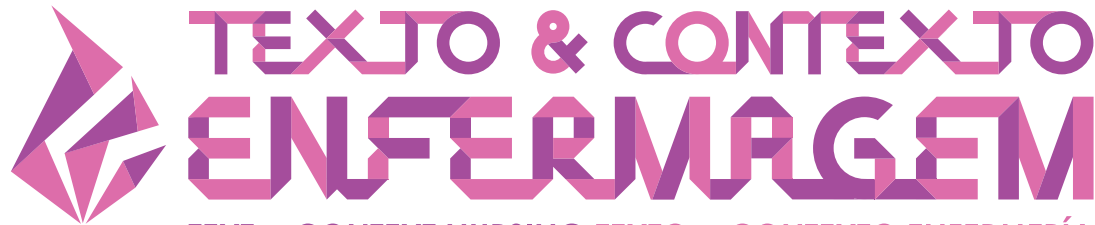

TEXT \& CONTEXT NURSING TEXTO \& CONTEXTO ENFERMERÍA

\section{DOMESTIC VIOLENCE EXPERIENCED BY ADOLESCENTS: THE DISCOURSE OF WOMEN EDUCATORS}

\author{
Kátia Cordélia Cunha Cordeiro ${ }^{1}$ \\ Nadirlene Pereira Gomes ${ }^{1}$ \\ Luana Moura Campos ${ }^{1}$ \\ Jéssica Damasceno de Santana' \\ Moniky Araújo da Cruz ${ }^{1}$ (C) \\ Rosana Santos Mota²
}

${ }^{1}$ Universidade Federal da Bahia, Escola de Enfermagem. Salvador, Bahia, Brasil. ${ }^{2}$ Universidade Federal da Bahia, Complexo Hospitalar Professor Edgar Santos. Salvador, Bahia, Brasil.

\begin{abstract}
Objective: to learn the perception of women educators about domestic violence against adolescents.

Method: this is a qualitative study, based on Paulo Freire's Critical-Liberating Perspective, conducted with 20 women educators from a public elementary school located in Salvador, Bahia, Brazil. An interview was conducted from August to October 2017. Data was systematized based on the Collective Subject Discourse and analyzed in the light of theorist Paulo Freire.

Results: the women educators' speeches about domestic violence against adolescents revealed perceptions represented by the "Forms of violence against adolescents practiced in the domestic setting"; "Repercussions of domestic violence on health and education"; "Naturalization of domestic violence"; and "Reproduction of violence in the school space".

Conclusion: women educators recognize domestic violence as an intergenerational phenomenon that expresses itself in various ways and has repercussions on the physical and mental health of adolescents with repercussions on school performance and interpersonal relationships, including with peers and teachers.

DESCRIPTORS: Domestic violence. Adolescent. School teachers. Elementary and high school. Nursing in community health.
\end{abstract}




\section{VIOLÊNCIA DOMÉSTICA VIVENCIADA POR ADOLESCENTES: DISCURSO DE EDUCADORAS}

\section{RESUMO}

Objetivo: apreender a percepção de educadoras acerca da violência doméstica contra adolescentes.

Método: trata-se de um estudo qualitativo, fundamentado na Perspectiva Crítico-Libertadora de Paulo Freire, realizado com 20 educadoras de uma escola pública de ensino fundamental localizada em Salvador, Bahia, Brasil. Realizou-se entrevista no período de agosto a outubro de 2017. Os dados foram sistematizados com base no Discurso do Sujeito Coletivo e analisados à luz do teórico Paulo Freire.

Resultados: os discursos das educadoras acerca da violência doméstica contra adolescentes revelaram percepções representadas pelas "Formas de violência contra adolescentes praticadas no ambiente doméstico"; "Repercussões da violência doméstica para a saúde e educação"; "Naturalização da violência apreendida no âmbito doméstico"; e "Reprodução da violência no espaço escolar".

Conclusão: as educadoras reconhecem a violência doméstica enquanto um fenômeno intergeracional que se expressa de diversas formas e repercute na saúde física e mental dos adolescentes com reflexos no desempenho escolar e nas relações interpessoais, inclusive com colegas e professores.

DESCRITORES: Violência doméstica. Adolescente. Professores escolares. Ensino fundamental e médio. Enfermagem em saúde comunitária.

\section{ADOLESCENTES VÍCTIMAS DE VIOLENCIA DOMÉSTICA: EL DISCURSO DE DOCENTES MUJERES}

\section{RESUMEN}

Objetivo: comprender la percepción de las docentes mujeres acerca de la violencia doméstica contra los adolescentes.

Método: se trata de un estudio cualitativo, fundamentado en la Perspectiva Crítico-Libertadora de Paulo Freire, realizado con 20 docentes mujeres de una escuela pública de enseñanza primaria en Salvador, Bahía, Brasil. Las entrevistas tuvieron lugar en el período de agosto a octubre de 2017. Los datos se sistematizaron en base al Discurso del Sujeto Colectivo y se los analizó a la luz del marco teórico de Paulo Freire.

Resultados: los discursos de las docentes mujeres acerca de la violencia doméstica contra los adolescentes revelaron las percepciones presentadas por las "Formas de violencia contra los adolescentes practicadas en el ámbito doméstico", por las "Repercusiones de la violencia doméstica para la salud y la educación", por la "Naturalización de la violencia comprendida en el ámbito doméstico" y por la "Reproducción de la violencia en el espacio escolar".

Conclusión: las docentes mujeres reconocen la violencia doméstica como un fenómeno intergeneracional que se expresa de diversas formas y repercute en la salud física y mental de los adolescentes, con efectos derivados en el desempeño escolar y en las relaciones interpersonales, inclusive con compañeros y profesores. DESCRIPTORES: Violencia doméstica. Adolescente. Profesores escolares. Enseñanza primaria y media. Enfermería en salud comunitaria. 


\section{INTRODUCTION}

Violence against children and adolescents represents a public health problem with serious compromises on physical and mental health, as well as for human development, and therefore essential actions to address this problem, which occurs predominantly in the domestic space. This context points to the need for articulated strategies, especially in education settings, as they are spaces where they meet most of the time.

Violence against children and adolescents is a matter of concern worldwide, especially in view of its higher incidence at home, where they should be protected. According to the United Nations Children's Fund (UNICEF), every seven minutes a person in childhood or adolescence is killed in the world as a result of violence. ${ }^{1}$ In the US, the mortality rate from violence in this age group ranges from 5 to $14 \% .^{2}$ In Brazil, in 2012 alone, there were 95,000 cases of aggression against children and adolescents who died. ${ }^{3}$

These cases commonly occur in the home setting, as indicated by a Brazilian research conducted in a public school with 239 students, whose report of intrafamily violence was present in $60.7 \%$ of the adolescents. ${ }^{4} \mathrm{~A}$ study that analyzed data from 171 countries also confirmed that the main perpetrators of this type of violence are the family members. ${ }^{5}$

Considering that the family is the primary institution with the duty to protect and care for children and adolescents, experiencing domestic violence, especially by their legal guardians, is a paradox. This is because the family represents the primary source of values, beliefs and attitudes, being the first reference of interaction and relationship for their children, which from then on may form new bonds. The construction of these elementary relationships is fundamental to human development, since part of each person's identity is related to what is transmitted from fathers and mothers to their children. ${ }^{6}$ Likewise, the school is a place of great influence on the formation of individuals and also has the responsibility to ensure that children and adolescents are safe and free from maltreatment and must report to the Guardian Council the identified cases, as indicated by the Child and Adolescent Statute (Estatuto da Criança e do Adolescente, ECA). ${ }^{7}$

It is noteworthy that experiencing domestic abuse also damages health and education. Nationwide studies and international surveys conducted in South Asia, Mexico, and the United States of America (USA) indicate that children and adolescents who witness and/or experience domestic violence tend to suffer physical or psychological harms such as depression, self-inflicted injuries, attempted suicide and suicide..$^{8-11}$ Such situations end up compromising school performance, situations of difficulty concentrating, dropping out and failing being common. ${ }^{12-13}$

The physical and mental illness of children and adolescents, with clear and direct implications on the behavior in the school space, points to the need for education and health professionals to be prepared to recognize and deal with the situation. In this perspective, we highlight the Health at School Program (Programa Saúde na Escola, PSE), established in 2007, by Decree No.6,286, whose purpose is to articulate health actions in the field of education, since educators, due to their closer relationship with the students, are in a strategic position to recognize the problem. ${ }^{14}$

Thus, it is essential to understand the perception of the educators about the phenomenon of domestic violence in adolescents in order to guide the practice of these professionals and those working in the health area to identify the problem. The study is also relevant from the premise that education intervenes in collective life, which contributes to the construction of a free and fair society. ${ }^{15}$ Thus, considering that domestic violence represents a form of domination still prevailing in our society, the salience of the relationship between educator-pupil is considered for the suspicion and identification of this problem, an essential condition for facing and overcoming this reality. In this sense, the study consisted of apprehending the perception of women educators about domestic violence against adolescents. 


\section{METHOD}

This is a study with a qualitative approach, based on Paulo Freire's Critical-Liberating Perspective, especially on its political and axiological principles. These are based on the idea that education is a form of intervention in the collective life, in the sense of maintaining or overcoming a given reality, as well as diffusing and producing values that govern people's lives. ${ }^{15}$

This research was conducted with 20 women educators from a public elementary school located in the outskirts of Salvador, Bahia, Brazil. The rapprochement with the teachers was supported by the Curriculum Action in Community and Society (Ação Curricular em Comunidade e em Sociedade, ACCS) entitled "Interdisciplinary and transdisciplinary approach to the health problems related to violence", which is part of the curricular structure of undergraduate courses at the Federal University of Bahia. This component favored the contact with the women educators, since during the period from 2013 to 2017, extension actions were developed for the students, having the following as themes of discussion: use/abuse of alcohol and other drugs, sexuality, bullying and domestic violence.

All permanent staff teachers who had been teaching at least six months at the school were invited to participate in the study. They received clarification as to the object and objectives of the research, its voluntary nature, the right to withdraw at any time, the absence of material or financial benefits in return for the collaboration, the guarantee of privacy and confidentiality of information and other ethical precepts contained in resolution 466/2012 of the National Health Council. There was no refusal by the guests, and all signed the Free and Informed Consent Form (FICF). A professional was not found after two contact attempts.

In the matrix project, characterizing the students of the locus-school, showed that $53.97 \%$ were men, which is why the terminology related to male students was adopted throughout the study.

Data collection was performed using the interview technique. The individual interviews were guided by a semi-structured form containing questions related to the sociodemographic aspects and the following guiding question: What is your perception about domestic violence experienced by adolescents? This stage took place from August to October 2017 in a reserved room at the locusschool in order to promote a space of privacy, trust and respect between interviewer and collaborators.

The statements were recorded, transcribed in full with the permission of the collaborators and systematized through the Collective Subject Discourse. This method consists in the grouping of speeches in order to construct a unique, first-person discourse so as to synthesize the understanding of a collectivity. From the transcribed interviews, the Central Ideas (Cls) and their Key Expressions (KEs) were removed. The $\mathrm{Cl}$ succinctly names the nuclear meaning of the speech, whereas the KEs are the lines that compose it. It is noteworthy that the data were validated by the collaborators, who received codes with an "E" from women Educators and the number referring to the transcription order of the interviews. Finally, the speech was interpreted and grounded according to Paulo Freire's Critical-Liberating Perspective.

\section{RESULTS}

Of the 20 collaborators interviewed, most were women (70\%), an event by which the terminology was adopted in the feminine and, for example, the expression "women educators" means both female and male educators. All of them were teachers, and their predominant employment relationship was that of state public servants, employed on a 20 -hour (45\%) or 40 -hour (55\%) weekly basis. The time spent in education ranged from four to 37 years and, in that institution, from six months to 26 years. 
All had a college degree and almost all, a specialization (90\%). Regarding knowledge about violence, a little more than half (55\%) mentioned that the theme was not addressed in undergraduate studies, in contrast to the large portion $(90 \%)$ who stated that they worked on this object during their specialization, especially in the curricular components attended $(20 \%)$.

Regarding the collective discourse, it reveals that, according to the women educators' perception, domestic violence experienced by school adolescents is based on four central ideas: expression of domestic violence in physical, psychological and negligent forms; repercussions of domestic violence on health and education; naturalization of domestic violence by adolescents; and reproduction of violence in the school space.

\section{Central Idea 1: Forms of violence against adolescents in the home setting}

Women educators perceive the domestic violence experienced by schoolchildren as a phenomenon expressed in various ways, referring, for example, to physical aggression, name calling and affective neglect, with food and education.

Domestic violence is expressed in the physical form, in the aggressive way of treating the adolescent. However, violence is not only expressed in the body. I see violence as an abuse of physical but also psychological nature. The way you talk can be a kind of violence [...] when using the aggressive and authoritative tone of voice. I also consider violence to live in an insulting setting, which requires exerting screaming power. We realize that many students take on responsibilities that are not age-appropriate, such as taking care of the home and the siblings. What I notice a lot here is the neglect of the future of their children, because it is difficult to get their parents in school to accompany them. They have parents who stop sending their children to school; others who drive them out, leaving them with nothing to eat. Many do not receive love, affection, from the family and I think this is the greatest example of violence.

\section{Central Idea 2: Repercussions of domestic violence on health and education}

For the women educators, the experience of domestic violence has repercussions on the physical and mental health of adolescents, from bruising to suicidal behavior, as well as impairments regarding school performance.

Certainly, violence leaves marks on the adolescents and hinders their development. This is notorious! The repercussions are not only on the physical, such as the black eye, but also psychological, emotional. I realize that people who have suffered violence are withdrawn. Many have low self-esteem, become bewildered, cut themselves, attempt suicide. All that results in the lack of interest in their studies: they no longer want to know about school, they end up losing their grades. I can't say if being responsible for taking care of the siblings is violence, but I see that it brings damage to the studies, such as lack of concentration, and takes away the right of the person to enjoy the adolescent phase. [...] I believe these situations are related to family problems.

\section{Central Idea 3: Naturalization of domestic violence}

The teachers' discourse also reveals the perception of domestic violence as a naturalized behavior by adolescents, a situation that influences the acceptance of the domestic aggressions. Given the understanding of violence as a culturally accepted conduct, the study warns of the difficulty of the adolescents to recognize abuse as such, contributing to the persistence of disrespectful relationships.

Here [at school] we have violence 24 hours a day. The habit of talking aggressively, beating and catching is so natural that they do not realize that they are being violent with their peers and teachers. [...] it expresses itself in the way they talk to their colleagues: cursing each other, shouting 
at each other. They think this is normal treatment. The teenager first needs to recognize himself in a situation of violence. Sometimes the family itself is unaware of what violence is and therefore needs the other to identify. Most of the time, teenagers catch each other and think it's normal and so don't comment on this. I believe that the parents who attack themselves are also victims of their lives. And that goes from generation to generation. I think family violence is so natural that it is difficult to intervene.

\section{Central Idea 4: Reproduction of violence in the school space}

According to the women educators' understanding, the violence seized in the domestic space is perceived, naturalized and reproduced in the interaction with the other in the various spaces of coexistence, such as the school. The speech also refers to the transgenerational character of this problem.

I note that the aggressiveness of teenagers is a reflection of what they live at home. Children copy what their parents do. They are role models for children. So, their aggressive way of behaving with their colleagues is often a warning, because what we realize is that they bring to the classroom what they experience at home. When they have intolerant people at home, they usually end up being intolerant at school as well. If parents are violent in their way of speaking and acting, they also do so with their peers. The way in which they treat each other verbally, sometimes aggressively, with profanity, may be the result of this family life that many of them have. The physical aggressions are also reproduced at school. The world they live in is so violent that even jokes are beating. They end up projecting this violence they suffer on another colleague because they have not learned to communicate, to reflect. [...] When you have a conflict at school with your classmates, they will soon hit. [...] They are aggressive not only with their peers, but with their teacher as well. [...] became victims of this process.

\section{DISCUSSION}

The women educators' discourse reveals the perception of domestic violence as a phenomenon expressed in physical, psychological and negligent forms, since they understand that adolescents can live in a domestic space permeated by name calling, shouting, verbal and physical aggression, as well as situations. lack of love, affective and material attention and having to assume their own responsibilities for adults, an event that may deprive them of the rights advocated by the Statute of the Child and Adolescent (Estatuto da Criança e do Adolescente, ECA), such as leisure, sports and community life. These findings are in agreement with national studies, also with educators, who mention physical and verbal aggression and neglect as forms of domestic violence. ${ }^{16}$ International evidence also attests to the women teachers' understanding of these expressions of domestic violence against children and adolescents, such as research studies conducted in Turkey, Russia, Colombia and Brazil that converge on the teachers' perceptions of these manifestations. ${ }^{17-20}$

The fact that the teachers perceive the different facets of domestic violence experienced by their students is in line with Freire's assumptions, since it defends the need for the educator to understand the "discourse of the body", the features of the face, the gestures, many times, even stronger than orality. The school curriculum should not be purely based on syllabus content, and should take into consideration all the subjects involved in the educational process and their daily experiences, as they have a strong influence on world views and identities, which consequently affects learning. ${ }^{21}$

Importantly, in addition to the physical, psychological and negligent forms revealed by the interviewees and corroborated by national and international studies, adolescents may also experience sexual abuse. These typifications are legitimized as forms of violence by both the World Health Organization (WHO) and by legal provisions that guarantee the rights of children and adolescents 
in Brazil. ${ }^{7}$ However, the non-consideration of sexual abuse by the women educators warns of their difficulty in glimpsing the possibility that students are experiencing such abuse in their homes. Diverse research studies conducted in Australia and Spain warn of the pervasiveness of this situation, as even in countries where there is a responsibility to report sexual abuse, women educators do not have the competence to recognize it. ${ }^{22-23}$ This may be related to the fact that they do not assume such an eventuality, as the collective discourse pointed out.

It is important to take into account the possibility that they may have avoided discussion on this subject, perhaps because they consider it more invasive and more serious. However, the lack of discourse of the women educators about sexual violence can be glimpsed from the understanding that it is impossible for education to remain neutral in the face of certain realities. ${ }^{15}$

The discourse also denotes the perception of the women educators about the harmful nature of domestic violence, with serious implications for the health and education of adolescents. The study evidences the teachers' understanding that the experience of abuse leaves body marks, such as bruising, and triggers psychological damage, such as depressive and suicidal behavior. These consequences of domestic violence are also perceived by health professionals working in Family Health Units (Unidades de Saúde da Família, USFs). ${ }^{24}$

When it comes to mental illness, the teaching perception of self-inflicted injuries is worth mentioning. This is because the experience tends to manifest itself in the subject's body, affecting its corporeality, ${ }^{25}$ which consists in the capacity of the individual to feel and use the body as a tool of manifestation and interaction with the world. ${ }^{26} \mathrm{An}$ example of this is the self-inflicted injury, defined as the act of hurting oneself with the intention of relieving tensions or feelings that present varying degrees of intensity and may occur in any age group, but it has been more frequent among adolescents. This form of self-inflicted aggression, referred to in the discourse through suicidal act, often occurs by a radical attempt to break with a pain, in which the person is no longer able to deal with situations that cause them pain, as in the case of pain. domestic violence.

The discourse also reveals the perception of domestic violence as an offense that compromises school performance and the full development of the adolescent's potential, since learning difficulties have a direct impact on school performance. ${ }^{27}$ Corroborating, a study conducted in Norway with 7,343 students and in Brazil with 210 students showed a reduction in school performance in adolescents who experience violence in their homes. ${ }^{28-29}$ From Freire's perspective, there is no doubt that the conditions in which students live reflect on their understanding of their own world, their ability to learn and also to respond to life's challenges.

Another repercussion found by the women education professionals is the aggressive behavior of the adolescents with their peers, which they understand as a warning sign for the experience of domestic violence. According to the discourse, this way of interacting with the universe is established from what is apprehended in their relationships, especially with the family. This is because the family is where the first relationship of integration of human beings begins, which interferes in the formation of the behavioral patterns, which are transmitted from fathers to daughters. ${ }^{16}$ Thus, the adolescents' ways of acting are directed by what they consider to be natural, thus not perceiving their attitudes as violence. This trivialization is corroborated by a research carried out in different regions of Brazil to reveal that, despite claiming to live in hostile settings and with frequent situations of violence, few realize themselves in this situation. ${ }^{30}$

The lack of recognition that their actions are violent causes adolescents to reproduce it in interpersonal relationships, such as school. A research conducted with young people and educators from public and private schools in three municipalities of the states of Ceará, Minas Gerais and São Paulo, which aimed to analyze the meanings that violence takes on in different social contexts and 
the ways in which it manifests itself in daily school life, signaled to the behavioral changes due to domestic violence that can be expressed through juvenile delinquency. ${ }^{31}$

In Sweden, it was found that adolescents who experienced physical and emotional domestic violence and/or witnessed household conflicts between their parents were more likely to practice and be victims of bullying. ${ }^{32}$ Research studies conducted in Cúcuta and China also showed cases of aggression against teachers perpetrated by students who suffered domestic violence ${ }^{19,33}$ Similar findings were found in research studies conducted in the Pacific Island, New Zealand, and Europe of juvenile offenders, ${ }^{34}$ alerting to the harms of experiencing domestic violence.

Thus, it is important to pay attention to the way these students are projecting these disrespectful relationships between their peers and other individuals around them, such as the women teachers. Thus, it is essential to rethink the school dynamics in order to invest in pedagogical practices that include dialogs about family and harmonious coexistence, including offering these adolescents other models of relationships, based on respect and solidarity among peers. These ideas are also defended by the axiological principle, which starts from the premise that education must produce and disseminate positive values that contribute to the humanization and solidarity of the subjects. ${ }^{15}$

Such pedagogical/dialogical activities to stimulate solidarity, respect for diversity and cooperation can be carried out from the PSE which, in its guidelines, provides for the inter-sectoral expansion of the actions performed by the health and education systems with a view to comprehensive health care for children and adolescents, as well as the promotion of a culture of peace, thus strengthening the articulation of knowledge between the Unified Health System (Sistema Único de Saúde, SUS) and the Public Education Networks. ${ }^{7}$ Thus, the joint actions of these two spheres can promote communication, referral and resolution among schools and health facilities, ensuring attention to people, especially adolescents, in situations of violence.

In this process of health promotion, Nursing deserves attention, especially for integrating the reference team in the FHS and often assuming their coordination. Although diverse research studies indicate that there is little action in addressing and preventing domestic violence, the FHS professionals have been demonstrating their ability to recognize the vulnerability of adolescents to practice and suffer abuse. Therefore, in view of that scenario, it is essential to promote alternative and creative practices that value youth protagonism with a view to promoting health and a culture of peace. ${ }^{35}$ This new perspective on adolescent education can be used as a strategy to disrupt the naturalization of domestic violence, however established the family model has been. Precisely considering such realities, it is necessary to constantly fight against any form of oppression, in order to propose an educator's training based on an ethics of the development of human life in its various potentialities, promoting dignity and promoting the responsible autonomy of the subjects in relation to themselves and the community. ${ }^{15}$

The study is limited by the low potential of generalization, as it is carried out in a single public school in Salvador, Bahia, Brazil, and the results presented may differ in other institutions depending on the social and community context in which it is inserted. Moreover, the clipping of public schools may not represent the scenario of private institutions, so as to influence the experiences lived by students and women educators about domestic violence.

\section{CONCLUSION}

Women educators perceive domestic violence as a phenomenon with consequences for physical and mental health, as well as for the educational process of adolescents, who experience it in physical, psychological and neglect forms. Although sexual abuse has not been mentioned, the teachers express the complex nature of the phenomenon, understanding its roots in the process of 
naturalization of the disrespectful relationships experienced by adolescents within the family and reproduced in other spaces of interaction with each other, such as the school.

The perception of these professionals about domestic violence leads to the need for spaces in the school setting that transcends the contents, contemplating the affective and social demands perceived by the women educators, as advocated by Paulo Freire. Therefore, these spaces should provide the adolescent public with references of respectful and loving relationships, essential for this group to fully develop their potentials.

Therefore, articulation with other institutions is essential in order to provide opportunities for these spaces. In the meantime, the scenario of the FHS stands out, especially through the PSE, revealing the interface between the areas of health sciences and education. Therefore, the PSE is configured as an important means of support for the women educators, including investment in the process of approximation and understanding of the family dynamics of adolescents, as well as thinking of collective intervention strategies with schoolchildren aiming at a life free of violence.

\section{REFERENCES}

1. United Nations Children's Fund. A familiar face: Violence in the lives of children and adolescents [Internet]. New York(US): UNICEF;2017. [cited 2018 Apr 27]. Available from: https://www.unicef. org/publications/files/Violence_in_the_lives_of_children_and_adolescents.pdf

2. Alpaslan $A H$, Coşkun $K S ̧$, Yeşil $A$, Çobanoğlu $C$. A child death as a result of physical violence during toilet training. J. Forensic Leg. Med. [Internet]. 2014 [cited 2018 Apr 27];28: 39-41. Available from: https://dx.doi.org/10.1016/j.jflm.2014.10.002

3. Waiselfisz JJ. Mapa da Violência 2015: mortes matadas por armas de fogo [Internet]. Brasília DF(BR): 2015 [cited 2018 Abr 27]. Available from: http://www.mapadaviolencia.org.br/pdf2015/ mapaViolencia2015.pdf

4. Mota RS, Gomes NP, Estrela FM, Silva MA, Santana JD, Campos LM, et al. Prevalência e fatores associados à vivência de violência intrafamiliar por adolescentes escolares. Rev Bras Enferm [Internet]. 2018 [cited 2019 Mar 18];71(3):1022-9. Available from: https://dx.doi.org/10.1590/00347167-2016-0546

5. Devries K, Knight L, Petzold M, Merrill KG, Maxwell L, Williams A, et al. Who perpetrates violence against children? A systematic analysis of age-specific and sex-specific data. BMJ Paediatr Open [Internet]. 2018 [cited 2018 Mar 24];2(1):e000180. Available from: https://dx.doi.org/10.1136/ bmjpo-2017-000180

6. Mandelbaum B, Schraiber LB, D'Oliveira AFPL. Violência e vida familiar: abordagens psicanalíticas e de gênero. Saúde Soc [Internet]. 2016 [cited 2018 May 04];25(2):422-30. Available from: http:// dx.doi.org/10.1590/S0104-12902016145768

7. Brasil. Lei $n^{\circ} 13.431$ de 4 de abril de 2017: Estabelece o sistema de garantia de direitos da criança e do adolescente vítima ou testemunha de violência e altera a Lei no 8.069, de 13 de julho de 1990. Brasília, DF(BR); 2017 [cited 2018 May 2]. Available from: http://www.planalto. gov.br/ccivil_03/_ato2015-2018/2017/Lei/L13431.htm

8. Ferdousy EZ, Matin MA. Association between intimate partner violence and child morbidity in South Asia. J Heal Popul Nutr [Internet]. 2015 [cited 2016 Nov 10];33(1):16. Available from: https://dx.doi.org/10.1186/s41043-015-0016-y

9. Rivera LR, Hernández PR, Amezcua BP, Lépez AL, Castro F. Factores individuales y familiares asociados con sintomatología depresiva en adolescentes de escuelas públicas de México. Salud Publica Mex [Internet]. 2015 [cited 2018 May 12];57(3):219-26. Available from: http://www.scielo. org.mx/scielo.php?script=sci_arttext\&pid=S0036-36342015000300010\&lng=es\&nrm=iso 
10. Yoon S, Steigerwald S, Holmes MR, Perzynski AT. Children's Exposure to Violence: The Underlying Effect of Posttraumatic Stress Symptoms on Behavior Problems. J Trauma Stress [Internet]. 2016;29(1):72-9. Available from: https://dx.doi.org/10.1002/jts.22063

11. Magalhães JRF de, Gomes NP, Mota RS, Campos LM, Camargo CL de, Andrade SR de. Intrafamily violence: experiences and perceptions of adolescents. Esc. Anna Nery [Internet]. 2017 [cited 2018 May 10];21(1):e20170003. Available from: http://www.scielo.br/pdf/ean/v21n1/ en_1414-8145-ean-21-01-e20170003.pdf

12. Hildebrand NA, Celeri EHRV, Morcillo AM, Zanolli ML. Domestic violence and risk for mental health in childhood and adolescence. Psicol Reflex Crit [Internet]. 2015 [cited 2017 Mar 6]; 28(2):213-21. Available from: https://dx.doi.org/10.1590/1678-7153.201528201

13. Santos RM, Gomes NP, Mota RS, Gomes NP, Couto TM, Araújo GS. Reprovação escolar e aspectos sociais e de saúde: estudo transversal com adolescentes. Rev Baiana Enferm. 2017; 32:e21827: Available from: https://dx.doi.org/10.18471/rbe.v32.21827

14. Brasil. Decreto $n^{\circ} 6.286$ de 5 de dezembro de 2007. Institui o Programa Saúde na Escola (PSE), e dá outras providências. [Internet]. Brasília, DF(BR); 2007. Available from: http://www.planalto. gov.br/ccivil_03/_ato2007-2010/2007/decreto/d6286.htm\%3E

15. Freire P. Pedagogia do oprimido: saberes necessários à prática educativa. 41th ed. Rio de Janeiro(BR): Paz e Terra; 2005.

16. Costa AL, Teixeira KMD. O comportamento dos alunos na escola e sua relação com a violência doméstica na percepção dos educadores. Oikos Rev Bras Econ Doméstica [Internet]. 2017 [cited 2018 Apr 28]; 28(1):22-42. Available from: https://oikos.ufv.br/index.php/oikos/article/view/261/238

17. Özabaci N, Erkan Z. Metaphors about Violence by Preservice Teachers Metaphors about Violence by Preservice Teachers. Coll Antropol [Internet]. 2015 [cited 2018 Apr 28]; 39(1):193-201. Available from: https://pdfs.semanticscholar.org/d8e7/710e9b41fd51b387ccc22eaccd3f4c102fc0.pdf

18. Baeva IA, Zinchenko YP, Laptev VV. Psychological resources of modern Russian adolescents' resilience to violence in the educational environment. Psychol Russ State Art [Internet]. 2016 [cited 2018 Apr 27]; 9(3):159-72. Available from: https://dx.doi.org/10.11621/pir.2016.0311

19. Suárez AAG, Gélvez JAO, García PAM. Violence in school settings: perception of teachers on manifestations of violence in educational institut. Psicogente [Internet]. 2017 [cited 2018 Apr 26]; 20(37):89-98. Available from: https://dx.doi.org/10.17081/psico.20.37.2420

20. Magalhães JRF, Gomes NP, Campos LM, Camargo CL, Estrela FM, Couto TM. The expression of intrafamily violence: adolescent oral histories. Texto Contexto Enferm [Internet]. 2017 [cited 2018 Jul 02]; 26(4):e1730016. Available from: https://dx.doi.org/10.1590/0104-07072017001730016

21. Freire P. A educação na cidade. 4th ed. São Paulo(BR): Cortez; 2000.

22. Goldman JDG, Grimbeek P. Preservice Teachers' Sources of Information on Mandatory Reporting of Child Sexual Abuse. J Child Sex Abus [Internet]. 2015 [cited 2018 Apr 27]; 24(3):238-58. Available from: https://dx.doi.org/10.1080/10538712.2015.1009607

23. Flores MMM, Hernández VVM, Gámez GG. Teachers' Knowledge and Beliefs About Child Sexual Abuse. J Child Sex Abus [Internet]. 2016 [cited 2018 June 30]; 25(5):538-55. Available from: https://dx.doi.org/10.1080/10538712.2016.1189474

24. Silveira TB, Netto de Oliveira AM, Algeri S, Susin LRO, Baisch ALM, Marques LA, et al. The invisibility of psychological violence against children. J. Hum. Growth Dev [Internet]. 2016 [cited 2018 June 30]; 26(3):345. Available from: https://dx.doi.org/10.7322/jhgd.122818

25. Stoddard SA, Heinze JE, Choe DE, Zimmerman MA. Predicting violent behavior: The role of violence exposure and future educational aspirations during adolescence. J Adolesc [Internet]. 2015 [cited 2018 Apr 27]; 44:191-203. Available from: https://dx.doi.org/10.1016/j.adolescence.2015.07.017 
26. Silva LLG, Souza MCRF, Simões R, Moreira WW. Thoughts on corporeality in the context of integral education. Educ Rev [Internet]. 2016 [cited 2018 Apr 27];32(1):185-209. Available from: https://dx.doi.org/10.1590/0102-4698144794

27. Faermann L. Dificuldades de aprendizagem de crianças e adolescents da rede pública de ensino: um fenômeno multicausal. Interfaces Científicas Educ. 2016;4(3): 91-104. Available from: https:// periodicos.set.edu.br/index.php/educacao/article/viewFile/2503/1823

28. Strøm IF, Thoresen S, Wentzel-Larsen T, Dyb G. Violence, bullying and academic achievement: A study of 15-year-old adolescents and their school environment. Child Abuse Negl [Internet]. 2013 [cited 2017 Jul 24];37(4):243-51. Available from: https://dx.doi.org/10.1016/j.chiabu.2012.10.010

29. Santos RM, Gomes NP, Mota RS, Gomes NP, Couto TM, De Araújo GS. School failure and health and social aspects: a cross-sectional study with adolescentes. Rev Baiana Enferm [Internet]. 2018 [cited 2018 May 05]; 32:e21827. Available from: https://dx.doi.org/10.18471/rbe.v32.21827

30. Lira k, Hanna N. O que dizem as crianças? Uma consulta sobre violência a partir da percepção de crianças e adolescentes. Rio de Janeiro(BR): Instituto Iguarapé; 2016

31. Njaine K, Minayo MCS. Violência na escola: identificando pistas para a prevenção. Interface Comun Saúde Educ [Internet]. 2003 [cited 2018 Apr 27];7(13):119-34. Available from: https:// dx.doi.org/10.1590/S1414-32832003000200009

32. Lucas S, Jernbro C, Tindberg Y, Janson S. Bully, bullied and abused. Associations between violence at home and bullying in childhood. Scand. J. Public Health [Internet]. 2016 [cited 2018 Apr 27];44(1):27-35. Available from: https://dx.doi.org/10.1177/1403494815610238

33. Lin X, Li L, Chi P, Wang Z, Heath MA, Du H, et al. Child maltreatment and interpersonal relationship among Chinese children with oppositional defiant disorder. Child Abuse Negl [Internet]. 2016 [cited 2018 Apr 27];51:192-202. Available from: https://dx.doi.org/10.1016/j.chiabu.2015.10.013

34. Ioane J, Lambie I, Percival T. A Comparison of Pacific, Māori, and European Violent Youth Offenders in New Zealand. Int. J. Offender Ther. Comp. Criminol [Internet]. 2016 [cited 2018 Apr 27];60(6):657-74. Available from: https://dx.doi.org/10.1177/0306624X14560725

35. Vieira Netto MF, Deslandes SF. As Estratégias da Saúde da Família no enfrentamento das violências envolvendo adolescentes. Cien. Saude Colet [Internet]. 2016 [cited 2018 Apr 27]; 21(5):1583-95. Available from: https://dx.doi.org/10.1590/1413-81232015215.14542015 


\section{NOTES}

\section{ORIGIN OF THE ARTICLE}

This research is linked to the parent project entitled University and public school: seeking strategies to address the factors that interfere in the teaching/learning process, developed by the Violence, Health and Quality of Life (VID@) Research Group, from the Universidade Federal da Bahia.

\section{CONTRIBUTION OF AUTHORITY}

study desing: Cordeiro KCC, Gomes NP.

Data collection: Cordeiro KCC, Santana JD, Cruz MA, Mota RS.

Analysis and interpretation of data: Cordeiro KCC, Gomes NP, Campos LM, Santana JD, Cruz MA. Discussion of the results: Gomes NP, Campos LM, Santana JD, Cruz MA, Mota RS.

Writing and/or critical review of content: Gomes NP, Campos LM, Mota RS.

Review and final approval of the final version: Gomes NP, Campos LM.

\section{FINANCING INFORMATION}

Fundação de Amparo à Pesquisa no Estado da Bahia, FAPESB under Public Notice 028/2012 and Grant Agreement PES0052/2013

\section{ETHICS COMMITTEE IN RESEARC}

Approved by the Ethics Committee in Research with Human Beings of the Universidade Federal da Bahia Nursing School, Opinion No.384,208/2013/CAAE: 19576913.4.0000.5531.

\section{CONFLICT OF INTERESTS}

There is no conflict of interest.

\section{HISTORICAL}

Received: July 31, 2018

Approved: April 09, 2019

\section{CORRESPONDENCE AUTHOR}

Nadirlene Pereira Gomes

nadirlenegomes@hotmail.com 